\title{
緑内障の薬物治療の現状と今後の展望
}

\author{
嶋 澤 雅 光, ${ }^{*}$ 原 英 彰
}

\section{Current Status of the Pharmacological Treatment of Glaucoma and Its Prospects}

\author{
Masamitsu Shimazawa* and Hideaki Hara \\ Molecular Pharmacology, Department of Biofunctional Molecule, Gifu Pharmaceutical \\ University; 1-25-4 Daigaku-nishi, Gifu 501-1196, Japan.
}

(Received August 16, 2020)

\begin{abstract}
Glaucoma, the leading cause of blindness in adults, is a progressive neurodegenerative disease characterized by retinal ganglion cell (RGC) death. Currently, many intraocular pressure (IOP)-lowering drugs known to affect this disease progression have been developed as therapeutic agents. However, there are many cases of disease progression, even with sufficient IOP reduction. Therefore, newer therapeutic approaches other than IOP-lowering drugs are needed. To elucidate the pathogenesis of glaucoma and to develop therapeutic agents, the evaluation of RGCs is imperative, as their degeneration is the main cause of this disease. However, it is difficult to obtain RGCs from healthy individuals, let alone glaucoma patients. Therefore, research on the pathophysiology of glaucoma and drug discovery has not progressed sufficiently. Recent developments have made it possible to generate induced pluripotent stem (iPS) cells from the blood or skin of glaucoma patients and induce them to differentiate into RGCs to study the pathogenesis of glaucoma. In addition, drug repositioning for ophthalmological diseases such as glaucoma is one of the most active fields. Many of these repositioned drugs have found therapeutic applications in ophthalmology. Here, we introduce the current status of the pharmacological treatment of glaucoma and its prospects.
\end{abstract}

Key words_ _ intraocular pressure; drug repositioning; glaucoma; retinal ganglion cell

\section{1. はじめに}

緑内障は，成人における中途失明原因の第 1 位の 網膜神経節細胞死を特徵とする進行性の神経変性疾 患であり。緑内障の 40 歳以上の平均有病率は約 $5 \%, 20$ 人に 1 人の割合で存在するとされている (多治見スタディー).11) 緑内障は，「視神経と視野に 特徵的な変化を有し, 通常, 眼圧を十分に下降させ ることにより視神経障害を改善もしくは抑制し得る 眼の機能的構造的異常を特徽とする疾患である」と 定義されている [緑内障診療ガイドライン（第 4 版）．一方，わが国では緑内障全体のなかで眼圧が 正常範囲内の正常眼圧緑内障 (normal tension glaucoma； NTG）が $72.0 \%$ 占めることが明らかにさ れている。このように，眼圧が正常範囲内であるに もかかわらず緑内障性視神経症が進行する患者が多

岐阜薬科大学生体機能解析学大講座薬効解析学研究室 (干501-1196 岐阜市大学西 1-25-4)

*e-mail: shimazawa@gifu-pu.ac.jp

本総説は, 日本薬学会第 140 年会シンポジウム S02 で

発表した内容を中心に記述したものである.
く, その病態解明が求められている. その病態発症 及び進行に関して，エビデンスのある唯一のリスク 因子は眼圧であり，薬物又は手術治療により眼圧を 下降させることにより視野障害の進行を抑制できる

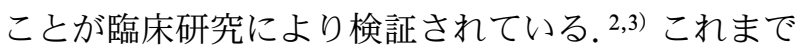
に多くの眼圧下降薬が開発されているが，十分な眼 圧下降作用が得られても病態が進行する例も少なく ない. ${ }^{3)}$ したがって，眼圧下降療法以外の新たな治 療アプローチが求められている. 緑内障の病態解明 並びに治療薬の創成のためには, その障害の主体と なる網膜神経節細胞を用いた評価が必要となる。し かし, その緑内障患者の網膜神経節細胞はおろか, 健常者の網膜神経節細胞も容易に入手することは難 しい. そのため, 緑内障の病態分子機構の研究及び 創薬研究はこれまで十分に進展しなかった：この課 題を解決する手段の 1 つとして, 緑内障患者の血液 又は皮膚などから人工多能性幹細胞（induced pluripotent stem cell; iPS 細胞) を作製し，それを 網膜神経節細胞に分化誘導することにより病態研究 を進めることが可能になつた。 また，緑内障を始め 
とする眼疾患治療薬の多くは他の疾患に用いられて いる既存の医薬品を眼科応用するドラッグ・リポジ ショニングが盛んな領域であり，多くの既存薬が眼 科応用されてきた．本稿では，緑内障のこれまでの 薬物治療の現状と課題, 並びに今後の展望について 紹介する.

2. 緑内障治療薬とドラッグ・リポジショニング 緑内障に対するエビデンスのある唯一確実な治療 法は眼圧下降療法である。 そのため, 視野障害が進 行する場合には正常眼圧緑内障のような眼圧が正常 範囲内でもさらに眼圧を下げる眼圧下降療法が行わ れる．現在，様々な作用機序を有する多くの眼圧下 降薬が開発され臨床応用されている，それらの眼圧 下降薬の中には, 他の疾患で用いられている全身薬 を眼科応用（ドラッグ・リポジショニング）したも のも少なくなく，眼科分野ではこのようなドラッ グ・リポジショニングが盛んに行われてきた。例え ば，緑内障治療薬である $\alpha_{1}$ 受容体遮断薬のブナゾ シン, $\beta$ 受容体遮断薬のカルテオロール, $\beta_{1}$ 受容体 遮断薬のベタキソロール及び $\alpha \beta$ 受容体遮断薬の二 プラジロールは, 本態性高血圧症などの治療薬とし て用いられており, それらが点眼薬として眼科応用 されてきた. 今後, 既存薬の作用を最新の分析手法 を用いて網羅的に分子レベルで解析し，他疾患の治 療薬としての可能性を検討する手法であるドラッ グ・リプロファイリングが推進されることが期待さ れる.さらに，眼疾患治療は局所投与が可能であり 全身性の副作用のリスクや投与量の制約が少ないこ とから, 強い副作用や不十分な薬効により開発中止 となった候補物質を眼科領域において新薬として再 利用（ドラッグ・レスキュー）できる可能性が期待 できる，製薬企業では，様々な理由から開発を断念 した多くの候補薬を保有しており，その貴重な資源 を再活用することにより画期的な新薬が生み出され ることが期待される。最近では，このような自社の 化合物を外部部提供して連携により新薬創出を目指 す「オープンイノベーション型創薬」が推進される ようになり，化合物ライブラリーを製薬企業間のみ ならず産学官で相互に利用する動きが活発になって きた. 今後, これらの研究成果が緑内障神経保護薬 の開発につながれることを期待したい.

\section{3. 緑内障神経保護薬のこれまでの取り組みと可} 能性

緑内障治療薬として, 眼圧下降薬以外の治療薬の 開発が進まない原因の 1 つしてて, 視野測定 (True endpoint) 以外の臨床評価指標が確立されて いないことが挙げられる，視野測定により薬効を評 価するためには, 数千名規模で評価期間が少なくと も 3 年以上の臨床試験を実施しなければならない. 米国アラガン社は, アルツハイマー型認知症治療剂 として使用されている $N$-methyl-D-aspartate （NMDA）型グルタミン酸受容体拮抗薬であるメマ ンチンによる緑内障の視機能維持を目的とした $2 つ$ の第 III 相臨床試験（NCT00141882, NCT00168350) をそれぞれ 1999 年及び 2000 年より開始し, 約 8 年 間かけて評価期間 48 力月，約 2298 名の患者におい て実施したが，プラセボ群との比較において明らか な視野障害進行抑制作用を実証できなかった. ${ }^{4)}$ の原因としては薬剂自体のポテンシャルの問題以外 に, 視野や眼底写真による評価指標の検出感度等に よる問題も大きいものと思われる。一方，眼圧下降 薬の治験では，眼圧下降により視野障害の進行を抑 制できることが臨床研究で検証されていることか ら，眼圧測定が視野測定以外の評価指標（Surrogate endpoint）として認められているため, 比較 的少数例かつ短期間で臨床試験を実施することがで きる．したがって，眼圧下降薬の視野進行に対する ランダム化比較試験は行われてこなかつた。その臨 床研究の中で, 神経保護の可能性を期待させる興味 深い研究成果が報告された。すなわち，正常眼圧緑 内障患者を対象とした海外での多施設共同無作為化 二重盲検比較試験 (low pressure glaucoma treatment study；LoGTS）において， $\alpha_{2}$ 受容体刺激薬で ある $0.2 \%$ ブリモニジン点眼製剤と $\beta$ 受容体遮断薬 である $0.5 \%$ チモール点眼製剤の視野障害の進行 を比較したところ，眼圧下降作用に 2 剂間で差がな かつたにもかかわらず視野障害の進行がチモロール 群 39\%に対して，ブリモニジン投与群 9\%と有意に

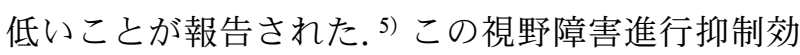
果は，ブリモニジンの神経保護作用による可能性を 示唆している.これまでの基礎研究において, ブリ モニジンは実験的緑内障モデル, 視神経挫滅モデル 及び眼虚血モデルなどの眼圧非依存的な網膜障害評 価系において保護作用を示すことが報告されてい 
(A)

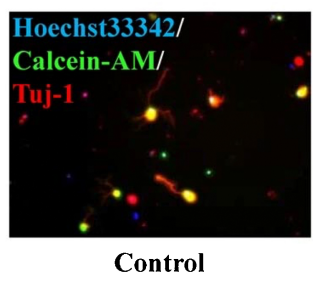

(B)

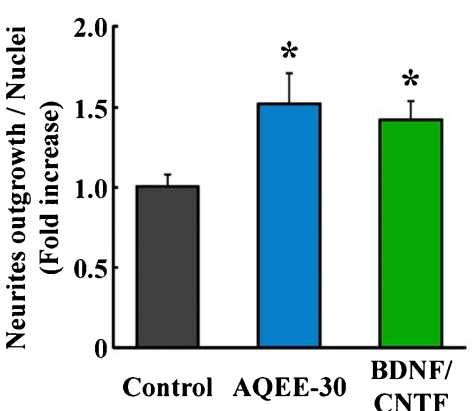

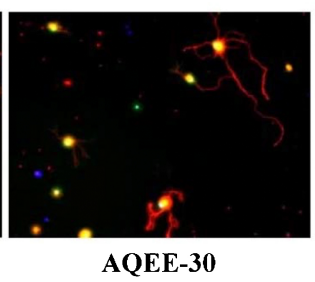

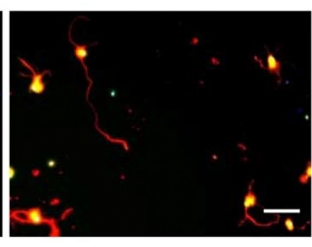

BDNF/CNTF

(C)

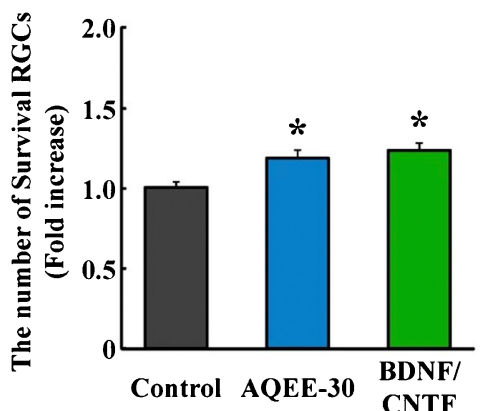

Fig. 1. AQEE-30, a VGF-derived Peptide, Promotes Neurite Outgrowth from Retinal Ganglion Cells (RGCs) in Vitro ${ }^{17)}$

(A) Typical images of cultured rat-derived RGCs at $3 \mathrm{~d}$ after purification. The neurites are stained by Calcein-AM ${ }^{+}$(green) and cells by Tuj- ${ }^{+}$(red). (B) Quantitative data showing the neurite lengths of RGCs. AQEE-30 at $1 \mu \mathrm{m}$ promotes neurite outgrowth in rat-derived RGCs. (C) Quantitative data showing surviving RGCs. Data are represented as the means \pm SEMs. ${ }^{*} p<0.05$ versus control group. Scale bar $=50 \mu \mathrm{m}$. (Color figure can be accessed in the online version.)

る. ${ }^{6)}$ ただし，この LoGTS 試験では比較対照薬で あるチモロール投与群の視野障害進行率が, 先行研 究の未治療対照群よりも高く, 3) 充血, 不快感, 過 敏症などの局所副作用の発生率はブリモニジン投与 群で明らかに高く，さらに 4 年間の治療観察期間中 の脱落率（ブリモニジン投与群 $55 \%$ ，チモロール 投与群 $29 \%$ ）も高かったことから，更なる検討が 必要であるとされている.7)

\section{4. 緑内障治療薬創生のアプローチ}

網膜神経節細胞死は, 緑内障を含む視神経症 [optic neuropathy（ON）; 虚血性視神経症，外傷 性視神経症，レーベル遺伝性視神経症など］に共通 する特徵である，網膜神経節細胞は，網膜の最も内 層にあり視神経軸索を網膜から脳の外側膝状体に直 接投射することにより，外界からの視覚情報を脳に 伝える役割を担つている，網膜神経節細胞死は，酸 化ストレス, ${ }^{8)}$ 興奮性アミノ酸, ${ }^{9}$ 一酸化窒素 (NO) ${ }^{10)}$ などの増加及び神経栄養因子（Neurotrophins）の減少11,12)など様々な因子が関与している ことが報告されている，なかでも，神経栄養因子を 治療ターゲットとした創薬研究が進めれられてお り，いくつかの視神経症をターゲット対象疾患とし
た臨床試験が実施されている。米国 Neurotech 社 は，神経栄養因子の 1 つである毛様体神経栄養因子 (ciliary neurotrophic factor; CNTF) を放出するよ うに遺伝子改変された不死化ヒ卜網膜色素上皮細胞 （RPE-19）をカプセル（長さ約 $6 \mathrm{~mm}$ ）に封入した レネクサス（Renexus； NT-501）を，眼内に留置す る徐放性デバイス（18 カ月にわたり持続的に放出） を用いて，緑内障を対象疾患とした第 2 相臨床試験 （NCT02862938）を実施した。本剂は，網膜中心部 である黄斑が両眼性に徐々に障害されることにより 視機能障害を呈する黄斑部毛細血管拡張症 2 型 (Macular Telangiectasia type 2) を対象疾患とした 第 2 相臨床試験（NCT01949324）が先行して実施 され，24 カ月の観察期間において網膜変性の進行 抑制効果が検出されており，13）第 3 相臨床試験 （NCT03319849, NCT03316300）が進められてい る.このように, 神経栄養因子の神経保護作用はこ れまでも期待されていたが, 生体内半減期が短いこ とや，標的組織や細胞への送達が難しいなどの薬物 送達技術（drug delivery system; DDS）や全身性副 作用により臨床応用が進まなかった．今後，上記の ような細胞又は薬物送達技術を応用することにより 
(A)

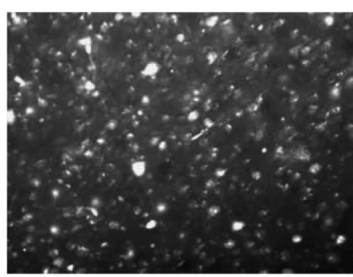

Sham

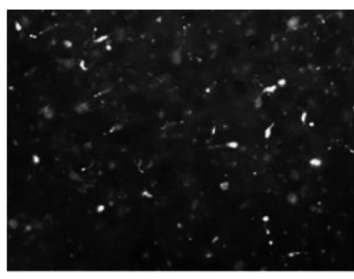

Vehicle

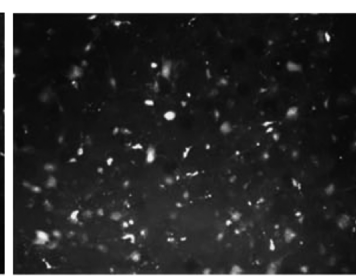

VGF

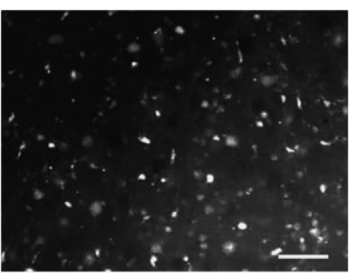

Brimonidine

ONC

(B)

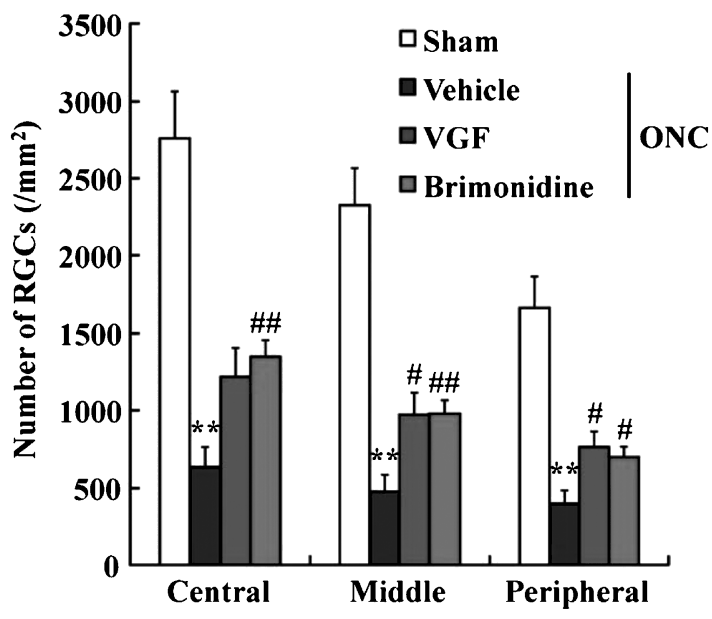

(C)

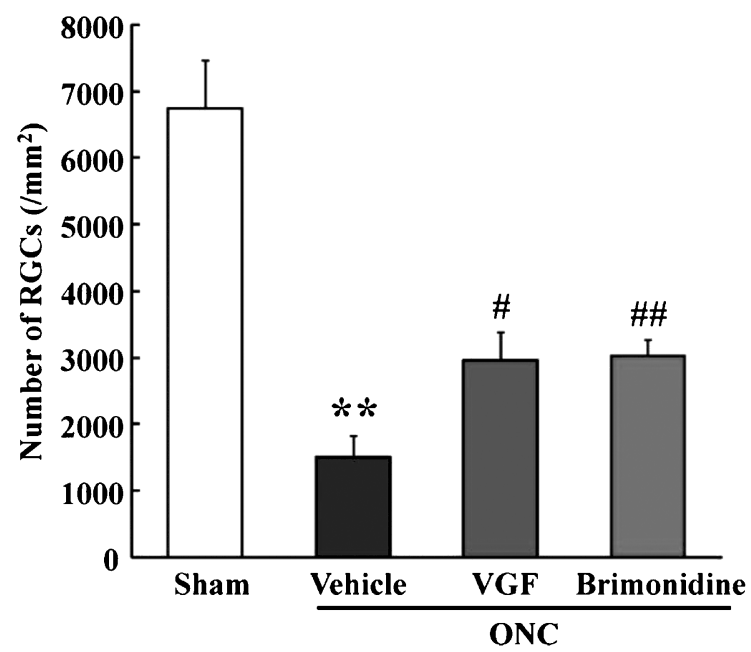

Fig. 2. AQEE-30 Suppresses the Loss of RGCs, but Does Not Change the Number of Microglia Induced by Optic Nerve Crush (ONC) ${ }^{17)}$

(A) Representative images showing fluorogold-labeled retinal ganglion cells (RGCs) in flat-mounted retinas at $10 \mathrm{~d}$ after the ONC. (B) The number of surviving RGCs was counted at the central, middle, and peripheral areas. (C) The total number of surviving RGCs is shown. AQEE-30 inhibited the loss of RGCs. Data are represented as the means \pm SEMs. ${ }^{* *} p<0.01$ versus sham group. ${ }^{\sharp} p<0.05,{ }^{\sharp} p<0.01$ versus vehicle-treated group. Scale bar $=50 \mu$ m.

臨床応用が推進されることが期待される.

近年，遺伝子治療薬の医薬品承認が相次いでいる が，眼科分野では初となる希少疾患遺伝性網膜ジス トロフィーの RPE65 両対立遺伝子変異患者（レー バー先天性黒内障）を対象疾患とした遺伝性眼科疾 患治療薬「ラクスターナ」が 2017 年にU.S. Food and Drug Administration（FDA）に承認された (日本では未承認)。ラクスターナ（Luxturna: voretigene neparvovec-rzyl）は，アデノ随伴ウイルスベ クター（AAV2-hRPE65v2）を用いた遺伝子治療薬 で, 治療開始時に網膜下に 1 回投与することで標的 細胞である網膜色素上皮細胞において正常な RPE65 タンパク質が恒常的に発現する。本治療に より患者の視機能は著明に改善し，その改善効果は 4 年後においても維持されていることが確認されて

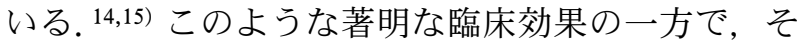
の治療には片眼で 42.5 万ドル, 両眼で 85 万ドル （約 9,000 万円）の医療費が必要となることが遺伝 子治療薬の大きな課題である. アステラス製薬株式 会社は，眼科領域における新規の遺伝子治療の開発 に注力する英国 Quethera 社を買収 (2018 年 8 月 10 日）し，緑内障患者の網膜に治療遺伝子を発現 させる遺伝子組換えアデノ随伴ウイルス（rAAV) を活用した遺伝子治療技術を獲得した，本技術は，

脳由来神経栄養因子 (brain-derived neurotrophic factor；BDNF）とその受容体 TrkB を同時に過剩発 現する遺伝子治療コンストラクト（AAV2 TrkB2A-mBDNF）により，リガンドと受容体を同時に 発現させ, 細胞生存経路を持続的に活性化されるこ とにより BDNF の効果を長期間維持するように設 
計された内容である. ${ }^{16)}$ AAV2 TrkB-2A-mBDNF は，マウスの眼硝子体内に投与することにより網膜 全層, 特に網膜神経節細胞及び視神経に両遺伝子産 物を 6 力月間にわたり発現させることが可能であ り，マウス視神経挫滅及び慢性高眼圧モデルによる 網膜神経節細胞死に対して保護作用を示すことが報 告されている. ${ }^{16)}$ このように遺伝子治療薬の開発が 加速することにより，治療法のない多くの難治性疾 患の治療が可能になることが期待される. しかし， 有効性が期待される反面，高額な医療費が予測され ることから緑内障のような有病率の高い疾患 (common disease) においては，若年発症の遺伝性 又は予後不良の進行性の患者層に限定して使用され ることが予想される.

筆者らは，緑内障病態解明の過程でマウス視神経 挫滅後の網膜及び視神経において神経分泌タンパク 質である VGF nerve growth factor inducible (VGF)

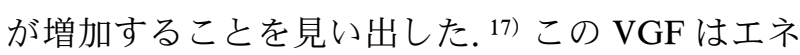
ルギーバランスの維持及び海馬シナプスの可塑性へ の関与が報告されている神経分泌タンパク質で, 神 経栄養因子である神経成長因子 (nerve growth factor; NGF) 及び BDNF により誘導されることが知ら れている. ${ }^{18,19)}$ 全長 VGF タンパク質は, プロホル モン転換酵素 $1 / 3$ 及び $2(\mathrm{PC} 1 / 3, \mathrm{PC} 2)$ により切断 され, $\mathrm{VGF}_{556-576}$ (TLQP 21), $\mathrm{VGF}_{588-617}$ (AQEE30) など 6 種類以上の VGF 由来ぺプチドが産生される ことが報告されている。これらの VGF 由来ぺプチ ドは, シナプス可塑性, 神経新生, 神経突起伸張作 用など神経機能の制御に重要な役割を担っており, 精神疾患及び神経変性疾患などの病態に深く関与し ていることが示唆されている. ${ }^{20)}$ 筆者らは, VGF 由来ペプチドの一種である AQEE30 がラット初代 培養網膜神経節細胞の細胞生存及び神経突起伸張促 進作用を有すること（Fig. 1)，さらにマウス視神 経挫滅後の網膜神経節細胞死に対して強力な細胞保 護作用を有することを明らかにした（Fig. 2). ${ }^{17)}$ AQEE30 の細胞保護作用及び神経突起伸展促進作 用は，BDNF/CNTF の併用効果をほぼ同等であっ た。このような中分子ペプチドをぺプチド修飾や DDS 技術により医薬品として応用できる可能性も 期待できる.

\section{5. まとめ}

緑内障治療神経保護の臨床開発は, メマンチンの
臨床試験（検証試験）の失敗から 10 年以上ほとん ぞ進展しなかったが, 臨床評価指標の改善, 遺伝子 治療薬の可能性などを契機にようやく進みはじめ た. 今後, 更なる技術革新や病態研究の進展により 画期的な治療薬が開発されることを期待したい.

利益相反＼cjkstart開示すべき利益相反はない.

\section{REFERENCES}

1) Suzuki Y., Yamamoto T., Araie M., Iwase A., Tomidokoro A., Abe H., Shirato S., Kuwayama Y., Mishima H. K., Shimizu H., Tomita G., Inoue Y., Kitazawa Y., Nippon Ganka Gakkai Zasshi, 112, 1039-1058 (2008) .

2) Collaborative Normal-Tension Glaucoma Study Group, Am. J. Ophthalmol., 126, 498505 (1998).

3 ) Collaborative Normal-Tension Glaucoma Study Group, Am. J. Ophthalmol., 126, 487497 (1998).

4) Weinreb R. N., Liebmann J. M., Cioff G. A., Goldberg I., Brandt J. D., Johnson C. A., Zangwill L. M., Schneider S., Badger H., Bejanian M., Ophthalmology, 125, 1874-1885 (2018).

5) Krupin T., Liebmann J. M., Greenfield D. S., Ritch R., Gardiner S., Am. J. Ophthalmol., 151, 671-681 (2011).

6) Saylor M., McLoon L. K., Harrison A. R., Lee M. S., Arch. Ophthalmol., 127, 402-406 (2009).

7) Sena D. F., Lindsley K., Cochrane Database Syst. Rev., (1), CD006539 (2017).

8) Bonne C., Muller A., Villain M., Gen. Pharmacol., 30, 275-280 (1998).

9) Dreyer E. B., J. Glaucoma, 7, 62-67 (1998).

10) Neufeld A. H., J. Glaucoma, 7, 434-438 (1998) .

11) Ghaffariyeh A., Honarpisheh N., Shakiba Y., Puyan S., Chamacham T., Zahedi F., Zarrineghbal M., Optometry, 80, 635-638 (2009) .

12) Oddone F., Roberti G., Micera A., Busanello A., Bonini S., Quaranta L., Agnifili L., Manni G., PLoS One, 12, e0168565 (2017).

13) Chew E. Y., Clemons T. E., Jaffe G. J., Johnson C. A., Farsiu S., Lad E. M., Guymer R., Rosenfeld P., Hubschman J. P., Constable I., 
Wiley H., Singerman L. J., Gillies M., Comer G., Blodi B., Eliott D., Yan J., Bird A., Friedlander M., Ophthalmology, 126, 540-549 (2019).

14) Maguire A. M., Russell S., Wellman J. A., Chung D. C., Yu Z. F., Tillman A., Wittes J., Pappas J., Elci O., Marshall K. A., McCague S., Reichert H., Davis M., Simonelli F., Leroy B. P., Wright J. F., High K. A., Bennett J., Ophthalmology, 126, 1273-1285 (2019) .

15) Russell S., Bennett J., Wellman J. A., et al., Lancet, 390, 849-860 (2017).

16) Osborne A., Khatib T. Z., Songra L., Barber A. C., Hall K., Kong G. Y. X., Widdowson P. S., Martin K. R., Cell Death Dis., 9, 1007 (2018).
17) Takeuchi H., Inagaki S., Morozumi W., Nakano Y., Inoue Y., Kuse Y., Mizoguchi T., Nakamura S., Funato M., Kaneko H., Hara H., Shimazawa M., Sci. Rep., 8, 16443 (2018) .

18) Bozdagi O., Rich E., Tronel S., Sadahiro M., Patterson K., Shapiro M. L., Alberini C. M., Huntley G. W., Salton S. R., J. Neurosci., 28, 9857-9869 (2008) .

19) Alder J., Thakker-Varia S., Bangasser D. A., Kuroiwa M., Plummer M. R., Shors T. J., Black I. B., J. Neurosci., 23, 10800-10808 (2003).

20) Mizoguchi T., Hara H., Shimazawa M., Cell. Mol. Neurobiol., 39, 721-727 (2019). 